\title{
Agroecological engineering
}

\author{
Françoise Lescourret ${ }^{1} \cdot$ Thierry Dutoit $^{2} \cdot$ Freddy Rey $^{3,7} \cdot$ François Côte $^{4}$. \\ Marjolaine Hamelin $^{5} \cdot$ Eric Lichtfouse $^{6}$
}

Published online: 19 October 2015

(C) INRA and Springer-Verlag France 2015

Bring diversity back to agriculture. That's what made it work in the first place.

David R. Brower

\section{The need and bases of agroecological engineering}

Achieving food security on a global scale, adapting to climate and land use changes, and stopping the loss of biodiversity and degradation of ecosystems are major challenges faced by society today. Several international initiatives for better public policies have been launched to address these challenges.

This article is the Preface of the virtual issue Agroecological Engineering, published in the journal Agronomy for Sustainable Development (www. springer.com/journal/13593) of the French National Institute of Agricultural Research (http://www.inra.fr/en). Fast article access is available on the journal blog (www1.montpellier.inra.fr/agronomy-blog).

Françoise Lescourret

francoise.lescourret@avignon.inra

Thierry Dutoit

thierry.dutoit@univ-avignon.fr

Freddy Rey

freddy.rey@irstea.fr

François Côte

francois.cote@cirad.fr

Marjolaine Hamelin

Marjolaine.Hamelin@supagro.inra.fr

Eric Lichtfouse

Eric.Lichtfouse@dijon.inra.fr

1 Invited Virtual Issue Editor, INRA, UR1115 Plants and Cropping Systems in Horticulture, Domaine Saint Paul site Agroparc,

F-84914 Avignon cedex 9, France
Striking examples are the actions of the Food and Agriculture Organization (FAO), the Intergovernmental Panel on Climate Change (IPCC), the strategic plan for biodiversity 2011-2020, including the Aichi Biodiversity Targets, and the International Governmental Platform on Biodiversity and Ecosystem Services (IPBES) (Perrings et al. 2011). Agroecosystems include areas under cropping, animal husbandry, aquaculture and forestry. Agroecosystems cover about $40 \%$ of the terrestrial Earth surface. The sustainability of agroecosystems is receiving a special attention from international initiatives, as explained by De Schutter (2010) for FAO, Field et al. (2014) for IPCC, and in
2 Invited Virtual Issue Editor, CNRS, UMR IMBE CNRS-IRD, Avignon Université, Aix-Marseille Université, Site Agroparc, BP 61207, F-84911 Avignon Cedex 09, France

3 Invited Virtual Issue Editor, Irstea, UR EMGR Écosystèmes montagnards, 2 rue de la papeterie, BP 76, F-38402 Saint-Martin-d'Hères Cedex, France

4 Invited Virtual Issue Editor, Cirad, Département Performances des Systèmes de Production et de Transformation Tropicaux, Cirad, Avenue Agropolis, TA B-DIR / 09, F-34398 Montpellier Cedex 5, France

5 Managing Editor, Agronomy for Sustainable Development, INRA, UR0050 Laboratoire de Biotechnologie de IEnvironnement, Avenue des Etangs, F-11100 Narbonne, France

6 Chief Editor, Agronomy for Sustainable Development, INRA, UMR1347 Agroécologie, INRA, 17, rue Sully, F-21000 Dijon, France

7 Université Grenoble Alpes, Grenoble 38402, France 
the seventh target of Aichi Biodiversity Targets, aimed at managing sustainably agroecosystems by 2020 .

Agroecology is a science and a public movement that favours the development of sustainable agricultural systems (Altieri 1995; Dalgaard et al. 2003; De Schutter 2010; Lichtfouse et al., 2009a, 2009b, 2011). Agroecology holds the ecological intensification discourse, whereas classical agronomy holds the sustainable intensification discourse (Tittonell 2014). Diversity is seen as a benefit for agroecology and as a burden for classical agronomy. Agroecology studies mainly complexity, randomness and hysteresis, whereas classical agronomy focuses on predictability. Weiner (2003) suggested that agriculture should make a transition from classical production to ecosystem manipulation. Agroecology faces this challenge.

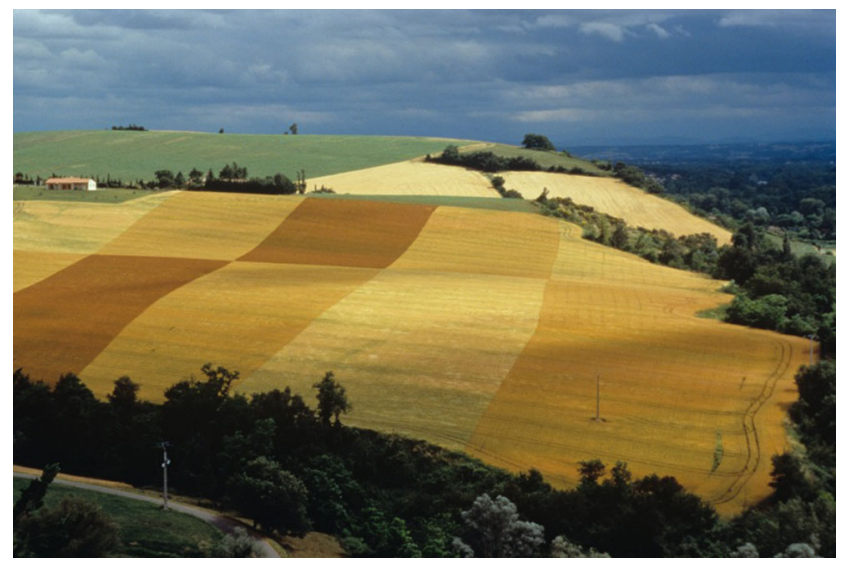

This land art photo taken near Toulouse, France, illustrates the diversity of crops and landscape . Copyright: Gilles CATTIAU/ INRA 1996.

Ecological engineering is the design of sustainable systems, consistent with ecological principles, which integrates human society with its natural environment for the benefit of both (Mitsch and Jørgensen 1989). Agroecological engineering is the modification of agricultural systems by applying ecological principles
(Vanloqueren and Baret 2009). Agroecological engineering was popular in China in the 1990s (Mitsch et al. 1993). Chinese agroecological engineering aims at developing simultaneously agricultural production and environmental protection (Yan et al. 1993; Zhang et al. 1998). Techniques are based upon the principles of holism, coordination, recycle and regeneration, and use a maximum of space and resources. Management combines both traditional techniques, such as the rice ridge and fish ditch system, and modern technologies such as mechanical or breeding technologies (Yan et al. 1993). A case study of a Chinese county where a plan of agroecological development was established has shown over 7 years $5.5 \%$ increase of grain yield, $37 \%$ reduction of farmland surface runoff, $50 \%$ reduction of soil loss and $144 \%$ increase of per capita income. Soil erosion was controlled by afforestation and protection of dykes and slopes, constructing terraced fields and planting ridge plants (Zhang et al. 1998).

The term "agroecological engineering" has seldom been used, except in China (Vanloqueren and Baret 2009). Agroecological engineering is rooted both in agronomy that provides knowledge on agroecosystem functions and design (Malezieux 2012) and in management sciences (Duru 2013). Wezel et al. (2014) classified agroecological practices in temperate areas according to the three stages of agroecological transition proposed by Hill and MacRae (1995): efficiency increase, substitution and redesign. The poor integration of these practices in current agriculture, noted by these authors, calls for a notable change of system. Agroecological engineering is also rooted in ecology, using principles of ecological engineering. Agroecological engineering shares challenges with conservation and restoration, which are the two classical fields of ecological engineering. These challenges are the design of practices using incomplete ecological knowledge, the introduction of planned biodiversity and the allowance of its self-maintaining in a more or less artificial ecosystem, and the control of the system (Barot et al. 2012).

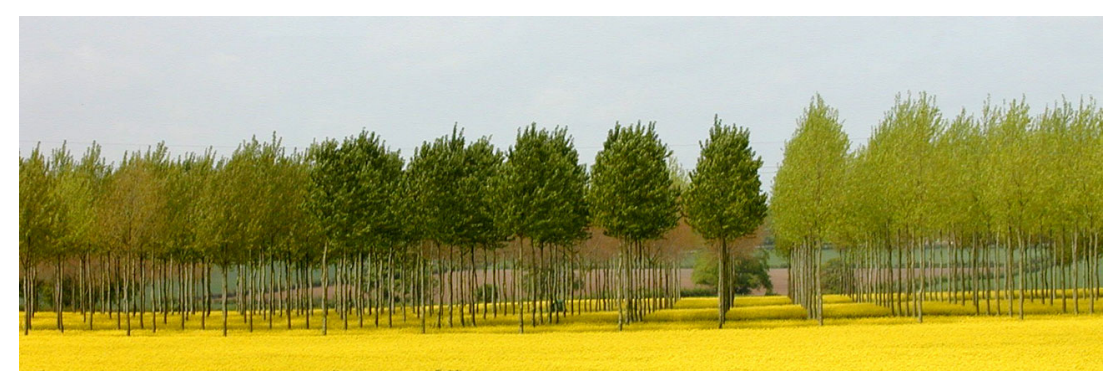

Agroforestry: an example of mutual benefits of cultivating two plant species, oilseed rape and poplar. Copyright: Christian DUPRAZ/INRA. 


\section{The agroecological engineering virtual issue}

The concepts of agroecological engineering are highlighted in a virtual issue gathering 19 reviews published in the journal Agronomy for Sustainable Development (www. springer.com/journal/13593). The articles are classified into four sections: positioning and societal challenges, conceptual and methodological frameworks, modelling, and management levers.

\subsection{Positioning and societal challenges}

The historical evolution of agroecology and its different approaches across countries reported by Wezel et al. (2009) question the positioning of agroecological engineering with respect to the three facets of agroecology presented by these authors: "a science" as a basis for agroecological engineering, "a practice" that corresponds to a technological dimension deeply inscribed in the notion of engineering, and "a movement" that concerns the initiatives of practitioners and calls for the study and support of the innovations they propose. Similar questions of positioning were encountered in ecological engineering (Rey and Gosselin 2014). The two following papers of this section, by M. Altieri and colleagues, give to agroecological engineering a sensitive engagement in the face of global challenges. The first one analyses and demonstrates, using case studies, the potential contribution of agroecologically efficient agricultural systems to food sovereignty in smallholder farms (Altieri et al. 2012). The second one discusses the design of farming systems resilient to climate change and places the emphasis on the diversification of these systems (Altieri et al. 2015). It considers traditional agroecosystems as a source of inspiration, in line with many authors (Malezieux 2012; Kremen et al. 2012; Vandermeer and Perfecto 2013).

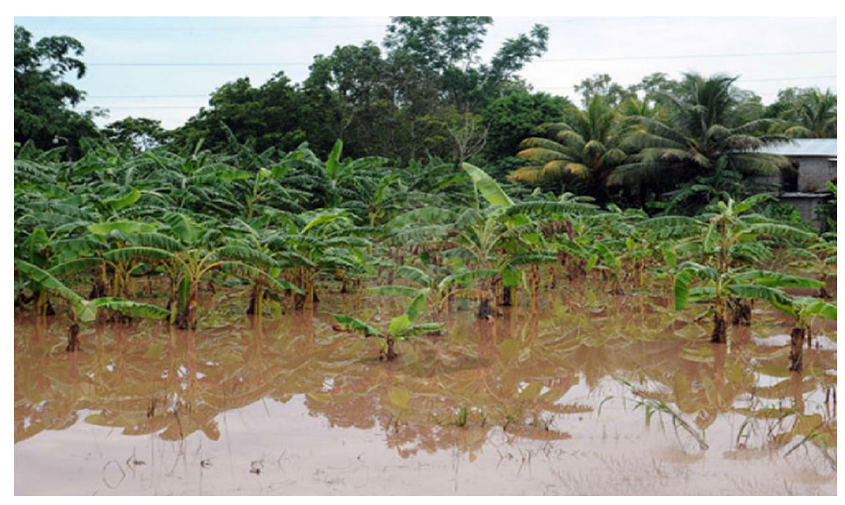

In tropical regions, increased precipitation will lead to flooding with serious effects on crop production as illustrated with this banana plantation in the Colombian Choco region. Altieri et al. 2015.

\subsection{Conceptual and methodological frameworks}

Rey et al. (2015) analyse the differences between ecological engineering and ecological intensification of agriculture, in terms of primary target ecosystem services-regulation versus provisioning - and the use of different kinds of inputs. The authors note the convergence of the two approaches with the diversification of target ecosystem services and the search for a sustainable support of underlying functions in each case. They propose to integrate approaches in a generic framework, from practice to ecosystem services delivery. Their contribution suggests that a central feature of agroecological engineering could be a convergence between ecological engineering and ecological intensification, directed at managing multiple ecosystem services and reaching acceptable tradeoffs in agricultural areas, where different groups of stakeholders produce or benefit from ecosystem services (Lescourret et al. 2015). Duru et al. (2015b) adopt the strong point of view of a biodiversity-based agriculture to enhance ecosystem services. They analyse the lack of practical application of agroecological principles and point out the key role of adaptive management and of learning tools tailored to the agroecological transition. This is an important route for agroecological engineering. The challenging issue of the agroecological transition is the object of a detailed reflection in this section. Duru et al. (2015a) propose to design the agroecological transition, following a five-step methodology, in a participatory framework, because of the social nature of the changes at stake. This stresses the need to consider together ecological and social issues in agroecological engineering and to use social-ecological frameworks tailored for agroecosystems (Lescourret et al. 2015).

Duru et al. (2015b) consider functional ecology concepts and methods, and particularly the trait approaches, to be central to the implementation of biodiversity-based management strategies. The trait approach is also presented as a conceptual foundation for ecological restoration by Laughlin (2014) who proposed a strategy to apply quantitative trait-based models to restore assemblages of indigenous species. In this section, Garnier and Navas (2012) review the trait approach in terms of concepts and methods. They demonstrate the value of this approach in an agroecological perspective by using examples on the agronomic value of grasslands and on the structure of weed communities in relation to agricultural production. The trait approach has not yet been very much tested for "planned biodiversity" - the biodiversity that is not spontaneous but chosen by the managers of agroecosystems. Damour et al. (2014) have found that the trait approach is efficient and timesaving for the phenotyping of cover plants aimed at providing several ecosystem services in banana cropping systems. However, Tribouillois et al. (2015), who applied the same approach, failed to precisely characterize and rank cover plants for the targeted agronomic purposes - reducing nitrate leaching and

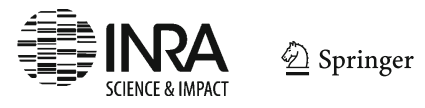


producing green manure-which they assumed to be the result of the domestication process that has modified the leaf trait syndrome.

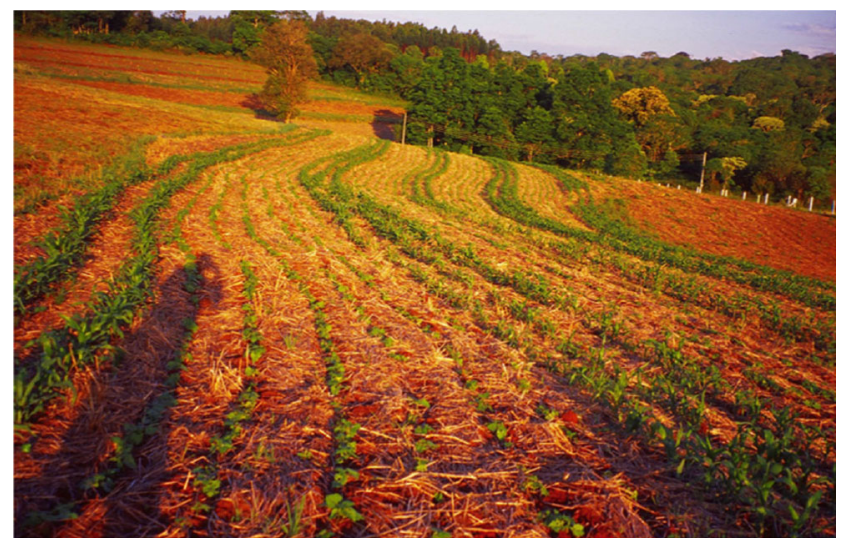

In Santa Catarina, southern Brazil, family farmers developed an organic no-till system which does not rely on herbicides. By flattening cover crop mixtures on the soil surface as a strategy to reduce soil erosion and lower fluctuations in soil moisture and temperature, these farmers improve soil quality enhancing weed suppression and crop performance. Altieri et al. 2015.

\subsection{Modelling}

Damos (2015) investigates the potential of web tools to improve the design and efficiency of decision support systems for pest management. He refers to the framework of integrated pest management (IPM) (Dent 1995), a concept born in the 1960s, which he considers as essential for the sustainability of agroecosystems. Even though Deguine et al. (2015) present "agroecological crop protection" as a further step of crop protection, the historical dimension and principles of IPM give IPM a key role in the reflection on agroecological engineering. Damos (2015) stresses the value of models for decision support.

More generally, models can integrate knowledge and help the design of management systems by exploring the consequences of various management options. Regarding the integration of knowledge, agroecological engineering requires a new generation of models able to represent a large range of agroecosystem functions. We should move from plant/animalbased models to agroecosystem models. As an option to materialize this idea and taking advantage of existing agronomic and ecological models in a unified framework, Tixier et al. (2013) suggest to link soil-plant models to food-web models able to cope with difficult issues such as pest regulation. Regarding the role of models in the design of management systems, Bellocchi et al. (2015) cover the issue of deliberative processes for the evaluation of agroecological models. They highlight the importance of such processes when models are used with and for stakeholders. During the model-based stage of a design process, one also needs efficient algorithms able to explore large solutions spaces and to generate a set of solutions reflecting appropriate trade-offs between the preferences of the different stakeholders involved. Memmah et al. (2015) address this problem using the example of land use optimization in agricultural landscapes. They review appropriate metaheuristics and analyse their use and their potential to deal with an increasing number of ecological functions and constraints, in a multi-actor framework.

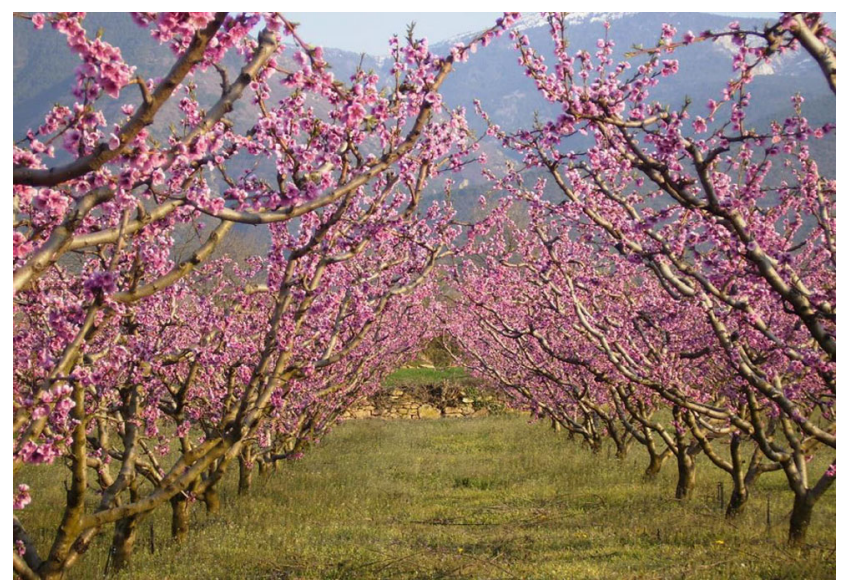

Typical integrated peach production orchard during the full bloom stage suited in Northern Greece, Prefecture of Kozaniwestern Macedonia. Damos 2015.

\subsection{Management levers}

Crop systems can be analysed using the grid of ecosystem services, in agreement with the fact that ecosystem services are presented as management targets in agroecosystems (Bommarco et al. 2013; Rey et al. 2015 and Duru et al. 2015b). The articles rely on the knowledge available on the ecological processes involved and on the influence of management practices on these processes. Some examples may concern several levers for a single service. Thus, Bodner et al. (2015) focus on the management of plant water stress with a view to mitigate the effect of drought on crop yields, a provisioning service. They perform an analysis of the subsystems of water flow through the soil-plantatmosphere continuum, from which they derive a series of soil and plant management options in different hydrological regimes. Deguine et al. (2015) introduce the notion of agroecological crop protection, which refers to a control of pests relying on ecological processes, a regulating service. They use the case of cucurbit flies in Reunion Island to illustrate this type of crop protection 
and the variety of techniques implemented, as well as their socioeconomic performances and adoption. Other examples deal with a single lever-generally a complex lever-for a more or less wide range of services. The issue of tradeoffs between services is sometimes evoked in these examples, which is consistent with the fact that management greatly affect the relationships between services (Bennett et al. 2009).

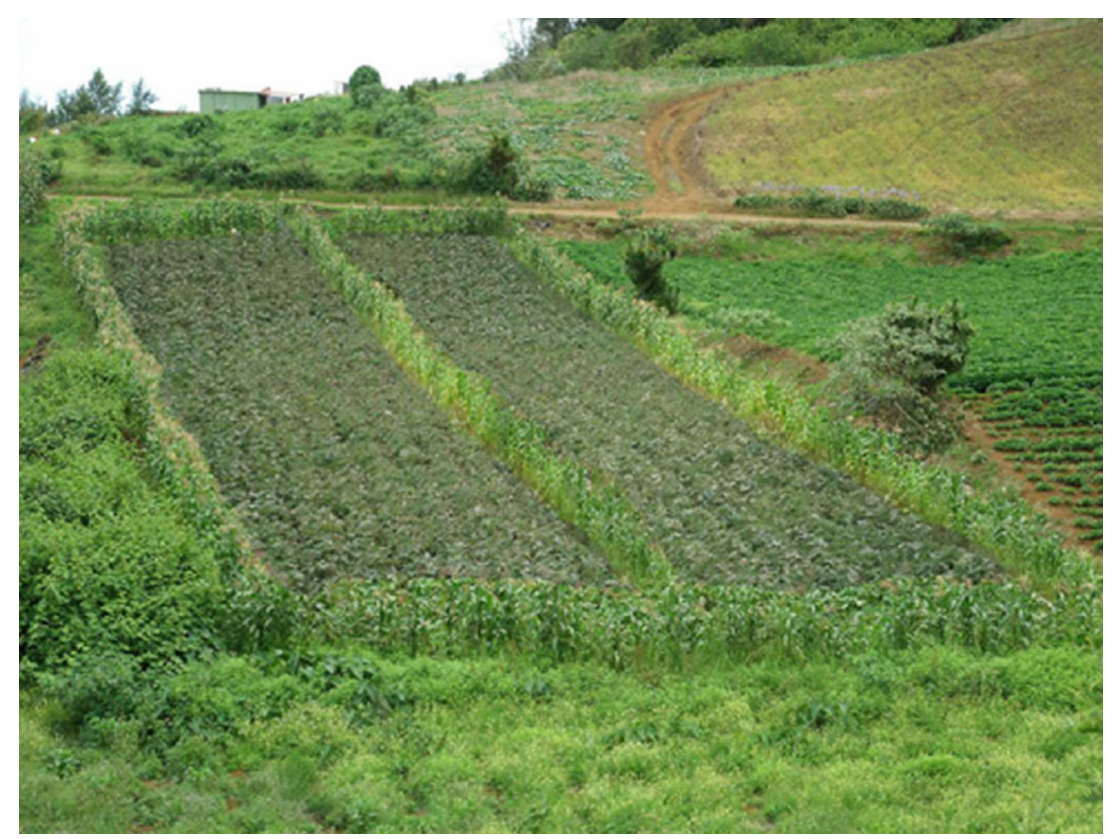

Trap crop plants such as maize plants bordering a zucchini crop field are used to attract pest and thus decrease pest damage. Deguine et al. 2015.

Bedoussac et al. (2015) demonstrate the benefit of cereal-grain legume intercropping in organic farming in terms of grain yield and quality (provisioning services) and weed control, a regulating service, by highlighting the underlying ecological processes. They also discuss the design of this complex lever, which includes the choices of species, varieties, plant densities and patterns and nitrogen fertilisation patterns. Gaba et al. (2015) analyse the functions underpinning the provision of pairs of services-food production and regulating services-in multiple cropping systems consisting of growing two or more cultivars or species in a spatial or temporal association. They derive guidelines to design multiple cropping systems aiming at finding appropriate tradeoffs between services. To this end, they rely on the trait approach detailed in Garnier and Navas (2012). Dollinger et al. (2015) review the role of ditches in a wide range of landscape services - regulation services dealing with soil and water processes, including water purification, and habitat provision. Having established the major ditch characteristics involved, they present the different ditch maintenance operations and their effect on those characteristics and services. Möller (2015) focus on anaerobic digestion, a treatment of biogenic wastes to fertilize soils. He investigates its role in the emission of greenhouse gases, a major factor of climate regulation, and in the functions involved in other services concerning the maintenance of biogeochemical conditions. He distinguishes direct effects from indirect effects due to the change in cropping systems that can accompany biogas plants implementation. The two last contributions focus on key groups of organisms providing or supporting ecosystem services. Bretagnolle and Gaba (2015) review the decline of weeds and bees and their complex links to pollination and crop production. They analyse management options for finding a good compromise, with emphasis on agroecological infrastructures in the landscape. Finally, Lemanceau et al. (2015) argue the importance of soil biodiversity and discuss management approaches to valorise it. These approaches include the introduction of beneficial microbial strains and the 
development of plant genotypes able to select beneficial communities within the rhizosphere.

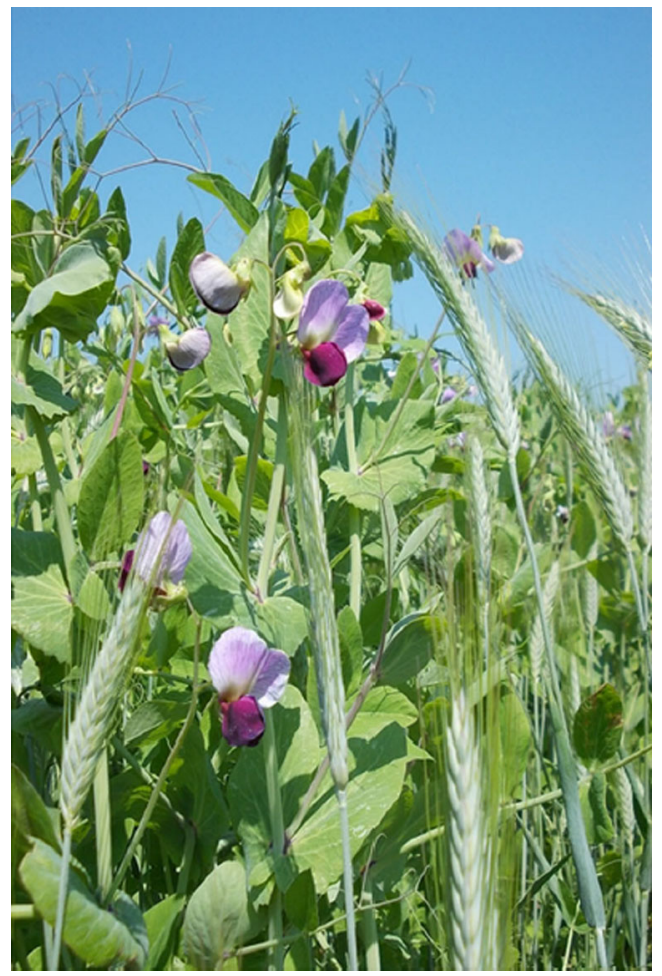

Cropping together triticale and pea allows to reduce the amount of mineral fertilisers added to the soil because pea fixes air nitrogen. Triticale is a hybrid of wheat and rye. Gaba et al. 2015.

\section{The future of agroecological engineering is open}

The virtual issue does not claim to offer a complete panorama of agroecological engineering. In particular, the genetics and breeding of crops, service plants and animals were just touched on in the issue (Gaba et al. 2015). However, it is a major challenge for agroecosystem diversification because of the impact of genotypic diversity on system productivity and resilience (Hughes et al. 2008; Tooker and Frank 2012; Altieri et al. 2015). For example, the support of genomics to the agroecological management of animal genetic resources is explained by Tixier-Boichard et al. (2015).

The design of multi-scale and multi-service management systems for an agroecological transition raises key research issues for agroecological engineering (Duru et al. 2015a, b; Gaba et al. 2015). In particular, the key issues are as follows: the combination of local knowledge and lay expertise with scientific knowledge (Dore et al. 2011), the design of new stakeholder organizations at the territory level, and the design of new coordination instruments combining scientific knowledge with perceptions, values and management skills of stakeholders (Lescourret et al. 2015). Overall, these issues illustrate the fact that agroecological engineering is a means to improve communication among research disciplines and between stakeholders and researchers (Hengsdijk and van Ittersum 2003).

Acknowledgments The virtual issue Agroecological Engineering has been initiated at a workshop on Ecological and Agroecological Engineering Approaches organised on 19 December 2013 by four French research institutes: INRA, Cirad, Irstea and CNRS in Montpellier, France. We thank Guy Richard (INRA), Jean-Marc Callois (Irstea) and Stéphanie Thiébault (CNRS), heads of divisions in these institutes, for their contribution during the workshop and support for the organisation and publication of this issue. We are grateful to the many participants to the workshop for helpful discussions and to the reviewers who helped in improving the manuscripts.

\section{References}

Altieri MA (1995) Agroecology: the science of sustainable agriculture. Westview Press, Boulder

Altieri MA, Funes-Monzote FR, Petersen P (2012) Agroecologically efficient agricultural systems for smallholder farmers: contributions to food sovereignty. Agron Sustain Dev 32(1):1-13. doi:10.1007/ s13593-011-0065-6

Altieri MA, Nicholls CI, Henao A, Lana MA (2015) Agroecology and the design of climate change-resilient farming systems. Agron Sustain Dev 35(3):869-890. doi:10.1007/s13593-015-0285-2

Barot S, Lata JC, Lacroix G (2012) Meeting the relational challenge of ecological engineering within ecological sciences. Ecol Eng 45:1323. doi:10.1016/j.ecoleng.2011.04.006

Bedoussac L, Journet EP, Hauggaard-Nielsen H, Naudin C, Corre-Hellou G, Jensen E, Prieur L, Justes E (2015) Ecological principles underlying the increase of productivity achieved by cereal-grain legume intercrops in organic farming. A review. Agron Sustain Dev 35(3): 911-935. doi:10.1007/s13593-014-0277-7

Bellocchi G, Rivington M, Matthews K, Acutis M (2015) Deliberative processes for comprehensive evaluation of agroecological models. A review. Agron Sustain Dev 35(2):589-605. doi:10.1007/s13593-0140271-0

Bennett EM, Peterson GD, Gordon LJ (2009) Understanding relationships among multiple ecosystem services. Ecol Lett 12(12):1394 1404. doi:10.1111/j.1461-0248.2009.01387.x

Bodner G, Nakhforoosh A, Kaul HP (2015) Management of crop water under drought: a review. Agron Sustain Dev 35(2):401-442. doi:10. 1007/s13593-015-0283-4

Bommarco R, Kleijn D, Potts SG (2013) Ecological intensification: harnessing ecosystem services for food security. Trends Ecol Evol 28(4):230-238. doi:10.1016/j.tree.2012.10.012

Bretagnolle V, Gaba S (2015) Weeds for bees? A review. Agron Sustain Dev 35(3):891-909. doi:10.1007/s13593-015-0302-5

Dalgaard T, Hutchings NJ, Porter JR (2003) Agroecology, scaling and interdisciplinarity. Agric Ecosyst Environ 100(1):39-51. doi:10. 1016/s0167-8809(03)00152-x

Damos P (2015) Modular structure of web-based decision support systems for integrated pest management. A review. Agron Sustain Dev. doi:10.1007/s13593-015-0319-9

Damour G, Dorel M, Quoc HT, Meynard C, Risede JM (2014) A traitbased characterization of cover plants to assess their potential to provide a set of ecological services in banana cropping systems. Eur J Agron 52:218-228. doi:10.1016/j.eja.2013.09.004 
De Schutter O (2010) Report submitted by the Special Rapporteur on the right to food. United Nations, General Assembly, Human Rights Council, Sixteenth session

Deguine JP, Atiama-Nurbel T, Aubertot JN, Augusseau X, Atiama M, Jacquot M, Reynaud B (2015) Agroecological management of cucurbit-infesting fruit fly: a review. Agron Sustain Dev 35(3): 937-965. doi:10.1007/s13593-015-0290-5

Dent D (1995) Integrated pest management. Chapman \& Hall, London

Dollinger J, Dages C, Bailly JS, Lagacherie P, Voltz M (2015) Managing ditches for agroecological engineering of landscape. A review. Agron Sustain Dev 35(3):999-1020. doi:10.1007/s13593-0150301-6

Dore T, Makowski D, Malezieux E, Munier-Jolain N, Tchamitchian M, Tittonell P (2011) Facing up to the paradigm of ecological intensification in agronomy: revisiting methods, concepts and knowledge. Eur J Agron 34(4):197-210. doi:10.1016/j.eja.2011.02.006

Duru M (2013) Combining agroecology and management science to design field tools under high agrosystem structural or process uncertainty: lessons from two case studies of grassland management. Agric Syst 114:84-94. doi:10.1016/j.agsy.2012.09.002

Duru M, Therond O, Fares M (2015a) Designing agroecological transitions: a review. Agron Sustain Dev. doi:10.1007/s13593-015-0318-x

Duru M, Therond O, Martin G, Martin-Clouaire R, Magne M-A, Justes E, Journet E-P, Aubertot J-N, Savary S, Bergez J-E, Sarthou J (2015b) How to implement biodiversity-based agriculture to enhance ecosystem services: a review. Agron Sustain Dev. doi:10.1007/s13593-015-0306-1

Field CB, Barros VR, Dokken DJ, Mach KJ, Mastrandrea MD, Bilir TE, Chatterje M, Ebi KL, Estrada YO, Genova RC, Girma B, Kissel ES, Levy AN, MacCracken S, Mastrandrea PR, White LL (2014) Contribution of working group II to the fifth assessment report of the intergovernmental panel on climate change. Climate change 2014: impacts, adaptation, and vulnerability. Part A: Global and Sectoral Aspects Cambridge University Press, Cambridge

Gaba S, Lescourret F, Boudsocq S, Enjalbert J, Hinsinger P, Journet EP, Navas ML, Wery J, Louarn G, Malézieux E, Pelzer E, Prudent M, Ozier-Lafontaine H (2015) Multiple cropping systems as drivers for providing multiple ecosystem services: from concepts to design. Agron Sustain Dev. 35(2):607-623. doi:10.1007/s13593-014-0272-z

Garnier E, Navas ML (2012) A trait-based approach to comparative functional plant ecology: concepts, methods and applications for agroecology. A review. Agron Sustain Dev 32(2):365-399. doi:10.1007/ s13593-011-0036-y

Hengsdijk H, van Ittersum MK (2003) Formalizing agro-ecological engineering for future-oriented land use studies. Eur J Agron 19(4): 549-562. doi:10.1016/s1161-0301(03)00002-9

Hill SB, MacRae RJ (1995) Conceptual framework for the transition from conventional to sustainable agriculture. J Sustain Agric 7(1):81-87

Hughes AR, Inouye BD, Johnson MTJ, Underwood N, Vellend M (2008) Ecological consequences of genetic diversity. Ecol Lett 11(6):609 623. doi:10.1111/j.1461-0248.2008.01179.x

Kremen C, Iles A, Bacon C (2012) Diversified farming systems: an agroecological, systems-based alternative to modern industrial agriculture. Ecology and Society 17(4):1-44. doi:10.5751/es-05103-170444

Laughlin DC (2014) Applying trait-based models to achieve functional targets for theory-driven ecological restoration. Ecol Lett 17(7):771784. doi:10.1111/ele. 12288

Lemanceau P, Maron PA, Mazurier S, Mougel C, Pivato B, Plassart P, Ranjard L, Revellin C, Tardy V, Wipf D (2015) Understanding and managing soil biodiversity: a major challenge in agroecology. Agron Sustain Dev 35(1):67-81. doi:10.1007/s13593-014-0247-0

Lescourret F, Magda D, Richard G, Adam-Blondon A-F, Bardy M, Baudry J, Doussan I, Dumont B, Lefèvre F, Litrico I, MartinClouaire R, Montuelle B, Pellerin S, Plantegenest M, Tancoigne E, Thomas A, Guyomard H, Soussana J-F (2015) A social-ecological approach to managing multiple agro-ecosystem services. Curr Opin Environ Sustain 14:68-75. doi:10.1016/j.cosust.2015.04.001
Lichtfouse E, Navarrete M, Debaeke P., Souchère V, Alberola C (2009a) (Eds) 2009b Sustainable Agriculture. Springer. 920 p. doi:10.1007/ 978-90-481-2666-8

Lichtfouse E, Navarrete M, Debaeke P., Souchère V, Alberola C, Ménassieu J (2009b) Agronomy for Sustainable Development. A review. Agro Sustain Dev 29(1):1-6. doi:10.1051/agro:2008054

Lichtfouse E, Hamelin, Navarrete M, Debaeke P. (2011) Sustainable Agriculture Volume 2. Springer. 992 p. doi:10.1007/978-94-0070394-0

Malezieux E (2012) Designing cropping systems from nature. Agron Sustain Dev 32(1):15-29. doi:10.1007/s13593-011-0027-z

Memmah MM, Lescourret F, Yao X, Lavigne C (2015) Metaheuristics for agricultural land use optimization. A rev Agro Sustain Dev 35(3): 975-998. doi:10.1007/s13593-015-0303-4

Mitsch WJ, Jorgensen SE (1989) Ecological engineering: an introduction to ecotechnology. Wiley, New York

Mitsch WJ, Yan JS, Cronk JK (1993) Ecological engineering - contrasting experiences in China with the West. Ecol Eng 2:177-191. doi: 10.1016/0925-8574(93)90013-6

Moller K (2015) Effects of anaerobic digestion on soil carbon and nitrogen turnover, $\mathrm{N}$ emissions, and soil biological activity. A review. Agron Sustain Dev 35:1021-1041. doi:10.1007/s13593-015-0284-3

Perrings C, Duraiappah A, Larigauderie A, Mooney H (2011) The biodiversity and ecosystem services science-policy interface. Science 331(6021):1139-1140. doi:10.1126/science. 1202400

Rey F, Gosselin F (2014) L'ingénierie écologique: des actions par et/ou pour le vivant, intégrées dans un projet d'ingénierie? In: Rey F, Gosselin F, Doré A (eds) Ingénierie écologique. Action par et/ou pour le vivant? Editions Quae, Versailles, pp 7-13

Rey F, Cécillon L, Cordonnier T, Jaunatre R, Loucougaray G (2015) Integrating ecological engineering and ecological intensification from management practices to ecosystem services into a generic framework: a review. Agron Sustain Dev. doi:10.1007/s13593015-0320-3

Tittonell P (2014) Ecological intensification of agriculture - sustainable by nature. Curr Opin Environ Sustain 8:53-61. doi:10.1016/j.cosust. 2014.08.006

Tixier P, Duyck PF, Cote FX, Caron-Lormier G, Malezieux E (2013) Food web-based simulation for agroecology. Agron Sustain Dev 33(4):663-670. doi:10.1007/s13593-013-0139-8

Tixier-Boichard M, Verrier E, Rognon X, Zerjal T (2015) Farm animal genetic and genomic resources from an agroecological perspective. Frontiers in Genetics. doi:10.3389/fgene.2015.00153

Tooker JF, Frank SD (2012) Genotypically diverse cultivar mixtures for insect pest management and increased crop yields. J Appl Ecol 49(5):974-985. doi:10.1111/j.1365-2664.2012.02173.x

Tribouillois H, Fort F, Cruz P, Charles R, Flores O, Garnier E, Justes E (2015) A functional characterisation of a wide range of cover crop species: growth and nitrogen acquisition rates, leaf traits and ecological strategies. Plos One. Doi:e012215610.1371/journal.pone.0122156.

Vandermeer J, Perfecto I (2013) Complex traditions: intersecting theoretical frameworks in agroecological research. Agroecol Sustain Food Syst 37(1):76-89. doi:10.1080/10440046.2012.717904

Vanloqueren G, Baret PV (2009) How agricultural research systems shape a technological regime that develops genetic engineering but locks out agroecological innovations. Res Policy 38(6):971-983. doi:10.1016/j.respol.2009.02.008

Weiner J (2003) Ecology - the science of agriculture in the 21st century. J Agric Sci 141:371-377. doi:10.1017/s0021859603003605

Wezel A, Bellon S, Dore T, Francis C, Vallod D, David C (2009) Agroecology as a science, a movement and a practice. A review. Agron Sustain Dev 29(4):503-515. doi:10.1051/agro/2009004

Wezel A, Casagrande M, Celette F, Vian JF, Ferrer A, Peigne J (2014) Agroecological practices for sustainable agriculture. A review. Agron Sustain Dev 34(1):1-20. doi:10.1007/s13593-013-0180-7 
Yan JS, Zhang YS, Wu XY (1993) Advances of ecological engineering in China. Ecol Eng 2(3):193-215. doi:10.1016/09258574(93)90014-7
Zhang RW, Ji WY, Lu BY (1998) Emergence and development of agroecological engineering in China. Ecol Eng 11(1-4):17-26. doi:10. 1016/s0925-8574(98)00041-x 